\title{
Understanding Plant Reproductive System Through Animated Videos with Project-Based Learning Activities
}

\section{* I Gst Ayu Irma Dewi Jumaheni', Ni Wayan Rati' ${ }^{2}$ I Komang Sudarma ${ }^{3}$}

1,2,3 Ganesha University of Education, Singaraja, Indonesia

\section{ART I CLE IN F O}

Article history:

Received March 09, 2021

Revised April 15, 2021

Accepted April 30, 2021

Available online May 25, 2021

Kata Kunci

Media Video Animasi, Project

Based Learning

Keywords:

Animation Video Tutorial,

Project-Based Learning

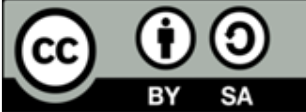

This is an open access article under the CC BY-SA license.

Copyright (ㄷ) 2021 by Author. Published by Universitas Pendidikan Ganesha.

\begin{abstract}
A B S TRAK
Penelitian ini dilakukan berdasarkan permasalahan minimnya media pembelajaran yang dapat digunakan baik melalui pembelajaran daring maupun luring pada situasi pandemi Covid-19 yang membatasi pembelajaran tatap muka. Tujuan utama penelitian ini adalah untuk mengetahui proses pengembangan serta validitas video animasi berorientasi project-based learning pada tema selamatkan makhluk hidup khususnya pada topik perkembangbiakan tumbuhan. Pengembangan media video animasi ini menggunakan model pengembangan ADDIE. Subjek penelitian pengembangan video animasi berorientasi project based learning adalah dua ahli isi materi, dua ahli desain pembelajaran, dua ahli media pembelajaran, uji coba perorangan, dan uji coba kelompok kecil. Metode pengumpulan data yaitu berupa kuesioner. Hasil analisis data menunjukkan bahwa rata-rata skor ahli materi sebesar 4,79 dengan kualifikasi sangat baik, ahli desain sebesar 4,65 dengan kualifikasi sangat baik, ahli media sebesar 4,62 dengan kualifikasi sangat baik, uji perorangan sebesar 4,8 dengan kualifikasi sangat baik, dan uji kelompok kecil sebesar 4,74 dengan kualifikasi sangat baik. Dengan demikian, hasil secara keseluruhan validitas media video animasi berorientasi Project Based Learning berada pada rentang 4,01 $<X \leq 5,01$ dengan kualifikasi "sangat baik". Jadi, media video animasi berorientasi Project Based Learning pada Tema Selamatkan Makhluk Hidup layak untuk digunakan dalam pembelajaran.
\end{abstract}

A B S T R A C T

This research was conducted based on the lack of learning media that can be used through online and offline learning in the Covid-19 pandemic situation, limiting face-to-face learning. The main purpose of this study was to determine the development process and the validity of project-based learningoriented animation videos on the theme of saving living things, especially on the topic of plant reproduction. The development of this animated video media used the ADDIE development model. The research subjects for developing project-based learning-oriented animation videos were two content experts, two learning design experts, two learning media experts, individual trials, and small group trials. The method of data collection was in the form of a questionnaire. The results of data analysis showed that the average score of material experts was 4.79 with very good qualifications, design experts 4.65 with very good qualifications, media experts at 4.62 with very good qualifications, individual tests of 4.8 with very good qualifications, and a small group test of 4.74 with very good qualifications. Thus, the overall validity of Project-Based Learning-oriented animation video media was in the range of $4.01<X 5.01$ with "very good" qualifications. So, Project-Based Learning-oriented animated video media on the theme of Save Living Creatures was feasible to use in learning.

\section{INTRODUCTION}

Since the end of 2019, the world has been paralyzed by the coronavirus. Coronavirus or other designations (Severe Acute Respiratory Syndrome Coronavirus 2/ SARS-CoV-2) is a virus that can attack the respiratory system, lung infection, and even death (Hincal \& Alsaadi, 2021; Singhal, 2020). This pandemic appears as a curse for mankind in the world. The emergence of this virus was initially detected in Wuhan, China, and then spread to several countries worldwide (Tambrallimath et al., 2021; Hincal \& Alsaadi, 2021; Mishra et al., 2020; K. Shah et al., 2020). The coronavirus transmission is so fast from individual to individual, and until now, there is no specific drug to treat Covid-19. This causes this virus to 
be very dangerous for humans (Kusumadewi et al., 2020). Covid-19 is the name for the disease caused by infection with the coronavirus (Baber, 2021; Guan et al., 2020; S. S. Shah et al., 2021). In addition to Covid itself, the congenital disease suffered by patients infected with the Covid-19 virus has a very high level of risk, so all of humanity must be more aware of this virus. Symptoms shown by patients infected with this virus vary from mild, moderate and fatal.

The global outbreak of Covid-19 began to enter Indonesia in March 2020. This made several citizens in Indonesia feel panicked, including the government, about the impact of this pandemic. The emergence of this pandemic has resulted in dramatic crises, especially in terms of the global economy and human social activities, including education (Tang et al., 2021). Education conducted face-to-face before the COVID-19 pandemic was forced to close to minimize the spread of the COVID-19 virus, which is taking more and more lives (Jogezai et al., 2021). Learning that should be delivered face-to-face, then anticipated by applying online learning as a whole in the middle of 2020 (Engelhardt et al., 2021; Ripoll et al., 2021). Technological advances that are developing rapidly can certainly provide a very important role for education to help teachers and students carry out online learning (Putri \& Dewi, 2020). Most teachers are not ready to prepare suitable learning media for elementary school students. The government must continue to encourage teachers to develop their competencies and skills to optimize online learning.

Teachers must develop their potential in creating innovative and interesting learning media for students in the current pandemic conditions. The media comes from Latin, namely medium, which can be interpreted as "intermediary" or "introduction" (Musfiqon, 2012). Media is a component of learning resources that contain instructional materials in the student environment that can stimulate students to learn (Sutirman, 2013). In learning, the media has a very important function, namely to help students in the learning process. The delivery of learning materials in an interesting way can improve students' understanding (Apriansyah, 2020). Learning media must have three main media elements, namely visual, sound, and motion, and are adapted to students' learning styles (Mustafida, 2016). Based on observations and interviews results, it is known that the learning media in the field are still very minimal. Teachers have been accustomed to conducting the learning process conventionally or directly, inevitably being required to study IT more deeply to create learning media that can be delivered online and easily understood by students. Apart from teachers, it is also important to evaluate local conditions, especially about facilities and the ability of parents to support online learning (Herliandry et al., 2020). Online learning in this pandemic condition certainly requires collaboration between teachers, parents, and students (Dewi, 2020). Some teachers have tried to create learning media to be delivered online, but the media made are not yet classified as professional because of time constraints, so that the quality of the media is less attractive to students. If the problem is not immediately addressed, it will greatly affect the interest in learning and students' activeness in participating in learning. This causes students to experience stress and get bored quickly in the online learning process (Jatira \& S, 2021).

Previous research that leads to the solution to these problems is to create animated video media. The development of the resulting animated video media can have a significant effect on students' activeness in participating in the learning process. This description is in line with previous studies, which state that the hands move animation video learning media with an environmental context is appropriate to use and can provide understanding to students (Permatasari et al., 2019). Another study that shows the effectiveness of animated videos on learning is a study which shows that the two-dimensional animation video learning media developed was declared valid and interesting by the experts (Agustien et al., 2018). Some of the next studies include research on the development of animated video media developed shows that animated videos in constructivism learning can improve learning outcomes (Juriah \& Juanengsih, 2016). Research on the development of animated video media developed shows that animated video media can improve learning outcomes (Noviyanto et al., 2015). Based on the relevant research, animated videos positively support online and offline learning in the current situation. However, in previous research, there are still things that need to be improved, such as adding projects related to the material by practicing it directly to have longer memories of the material being studied.

Animated video media is a form of technology that can help the learning process (Pradana et al., 2020). Animated videos will be more effective when combined with project-based learning models. Project-based learning is one of the learning models in which there are activities to design and work on a project to create a product related to the material presented (Ardianti et al., 2017). Project-based learning-oriented learning animation videos are 2-dimensional animated videos in which there are various subject matter subjects, and there is a project that will be discussed or discussed by students. This animated video media is suitable for elementary schools because it can provide direct, interesting, and funny experiences. According to Piaget's theory, elementary school-aged children are at a concrete operational stage that requires concrete objects at the time of learning (Trianingsih, 2016). They will find it difficult in the learning process without the help of media that can represent the thing in question 
(Fatimah Ibda, 2015). This is what causes the delivery of learning materials with the help of animated video media to optimize students' understanding and activeness. Animated video media is very appropriate to use to help deliver science learning materials, especially on plant reproduction. In the animated video, pictures and animations related to plant reproduction are clearly explained, making it easier for students to understand. In addition to attracting animated media, it can stimulate students' attention, interest, thoughts, and attention to the media displayed so that learning objectives are achieved because students can see the learning material being observed by using the sense of sight in learning, students' understanding will be more optimal and more concrete. The purpose of research on the development of project-based learning-oriented animation videos is to determine the development process and quality of project-based learning-oriented animation videos on saving living things, especially on the topic of plant reproduction, thus creating animated video media that have been tested for feasibility. With this research, it is expected to create media that is useful for teachers, students, and other researchers.

Based on the problems above, this study seeks to develop an animated video media oriented to project-based learning to help increase students' interest and activity in participating in learning, especially on the theme of Save Living Creatures, especially on the Topic of Plant Breeding. This animated video media also aims to determine the validity of the media on the interests and activities of sixth-grade elementary school students in receiving learning. This video is expected to help teachers and students in delivering and receiving learning materials independently but directed.

\section{METHOD}

According to Robert Maribe Branch, research on the development of animated video media on the theme of saving sentient beings for class VI SD refers to the ADDIE model (Fajar, 2019; Isya', 2017). Several stages are carried out in the development of animated video media, namely, analysis, design development, implementation, and evaluation. The analysis phase consists of curriculum analysis, student characteristics analysis, and analysis of learning support infrastructure. The design stage is carried out by collecting materials, identifying assignments/tests, compiling a product framework, and compiling costs. The development stage is carried out by creating content and selecting/making supporting media, developing student and teacher instructions/guidelines, conducting formative evaluations and revisions (expert tests, individual tests, and small group tests), test reports/formative results. In the implementation phase, field trials were carried out by looking at the preparation of students and teachers. The evaluation stage is carried out by determining evaluation criteria, selecting instruments, and conducting evaluations. Evaluation can be carried out in two stages, namely formative and summative ways. The formative evaluation aims to assess the feasibility of the product, while the summative evaluation aims to determine whether the product is effective or not.

The research subjects for developing project-based learning-oriented animation videos are two content experts, two learning design experts, two learning media experts, individual trials, and small group trials. Meanwhile, the object of the research is the validity of project-based learning-oriented animation video media. This research uses qualitative descriptive analysis method and quantitative descriptive analysis. Qualitative descriptive analysis in the form of responses and suggestions by experts on the media developed through the distribution of questionnaires. The questionnaire aims to determine the results of the evaluation of content experts, design experts, media experts, and sixth-grade elementary school students on the animated video media developed. Meanwhile, quantitative descriptive analysis in the form of data processing results from the score of the questionnaires filled out by the experts. The grid of instruments used for the validation test is shown in Table 1,2,3,4.

Table 1. The Blue Print of Content Expert Animation Video Validity Instrument

\begin{tabular}{llllc}
\hline No & \multicolumn{1}{c}{ Aspect } & \multicolumn{1}{c}{ Indicator } & Item Number \\
\hline 1 & The truth of the & a. & Conformity of basic competencies with indicators. & 1 \\
& material & b. & Conformity of learning objectives with indicators. & 2 \\
& structure & c. & The suitability of the material with the learning & 3 \\
& & d. & Beneftives. \\
\hline
\end{tabular}




\begin{tabular}{|c|c|c|c|}
\hline No & Aspect & Indicator & Item Number \\
\hline \multirow[t]{4}{*}{2} & \multirow[t]{4}{*}{ Content accuracy } & a. The truth of the material presented. & 5 \\
\hline & & $\begin{array}{l}\text { b. The accuracy of the material delivered by the } \\
\text { learning objectives. }\end{array}$ & 6 \\
\hline & & c. The novelty (update) of the material presented. & 7 \\
\hline & & $\begin{array}{l}\text { d. The accuracy of the presentation of the material is } \\
\text { based on the existing facts. }\end{array}$ & 8 \\
\hline \multirow[t]{3}{*}{3} & \multirow{3}{*}{$\begin{array}{l}\text { Grammatical } \\
\text { correctness }\end{array}$} & a. The accuracy of the grammar used. & 9 \\
\hline & & b. Spelling accuracy of the material. & 10 \\
\hline & & c. The accuracy of writing terms on the material & 11 \\
\hline 4 & $\begin{array}{l}\text { Correct } \\
\text { punctuation }\end{array}$ & $\begin{array}{l}\text { a. The accuracy of the use of punctuation in the } \\
\text { material. }\end{array}$ & 12 \\
\hline \multirow[t]{5}{*}{5} & \multirow{5}{*}{$\begin{array}{l}\text { The level of } \\
\text { difficulty of the } \\
\text { material is } \\
\text { adjusted to the } \\
\text { characteristics of } \\
\text { the user. }\end{array}$} & $\begin{array}{l}\text { a. The level of material breadth by the } \\
\text { characteristics of students. }\end{array}$ & 13 \\
\hline & & $\begin{array}{l}\text { b. The initial material is related to the students' } \\
\text { prior knowledge. }\end{array}$ & 14 \\
\hline & & c. Evaluation suitability. & 15 \\
\hline & & d. Completeness of the material presented. & 16 \\
\hline & & $\begin{array}{l}\text { e. Illustrations (examples) in learning media can } \\
\text { clarify the material presented. }\end{array}$ & 17 \\
\hline \multicolumn{2}{|c|}{ Total } & & 17 \\
\hline
\end{tabular}

Table 2. Blueprint of Instrument Validity Video Animation Learning Design Expert

\begin{tabular}{|c|c|c|c|}
\hline \multirow{2}{*}{$\begin{array}{l}\text { No } \\
1\end{array}$} & Aspect & Indicator & Item number \\
\hline & Accuracy & $\begin{array}{l}\text { a. The learning objectives are by the ABCD format. } \\
\text { b. The suitability of the video with the characteristics } \\
\text { of students. } \\
\text { c. The suitability of the material with the purpose. } \\
\text { d. The material in the learning video is presented } \\
\text { coherently. }\end{array}$ & $\begin{array}{l}2 \\
3 \\
4\end{array}$ \\
\hline 2 & Clarity & $\begin{array}{l}\text { a. The language used is easy for students to } \\
\text { understand. } \\
\text { b. Clarity of description and discussion. } \\
\text { c. Completeness of information in the material. } \\
\text { d. Instructions for using media. }\end{array}$ & $\begin{array}{l}5 \\
6 \\
7 \\
8\end{array}$ \\
\hline 3 & Interest/attention & $\begin{array}{l}\text { a. Interactivity. } \\
\text { b. Videos motivate interest in learning. } \\
\text { c. Increase students' attention to learning. }\end{array}$ & $\begin{array}{c}9 \\
10 \\
11\end{array}$ \\
\hline 4 & $\begin{array}{l}\text { The quality of the } \\
\text { test and its } \\
\text { assessment }\end{array}$ & a. Consistency of evaluation with learning objectives. & 12 \\
\hline 5 & $\begin{array}{l}\text { It can have an } \\
\text { impact on } \\
\text { students }\end{array}$ & a. Facilitate students' understanding of the material. & 13 \\
\hline Tota & & & 13 \\
\hline
\end{tabular}

Table 3. Blueprint of Instrument Validity Video Animation Expert Learning Media

\begin{tabular}{lllc}
\hline No & Aspect & \multicolumn{1}{c}{ Indicator } & Item number \\
\hline 1 & Visual Quality & a. & $\begin{array}{l}\text { The attractiveness of the CD cover to package } \\
\text { learning videos. }\end{array}$ \\
& b. $\begin{array}{l}\text { The suitability of the CD cover visualization to the } \\
\text { content in the media }\end{array}$ \\
& c. The attractiveness of the animation is shown. \\
& d. Writing clarity
\end{tabular}




\begin{tabular}{|c|c|c|c|}
\hline No & Aspect & Indicator & Item number \\
\hline & & e. Color Match & \\
\hline & & f. Layout & \\
\hline & & g. Image clarity & \\
\hline & & h. Background image compatibility & \\
\hline \multirow[t]{3}{*}{2} & Voice clarity & a. Narrator's voice clarity. & 3 \\
\hline & a. Narrative & b. Appropriate use of Sound Effects. & \\
\hline & b. Sound Effects & c. The attraction of the opening & \\
\hline \multirow[t]{4}{*}{3} & $\begin{array}{l}\text { Video } \\
\text { presentation }\end{array}$ & $\begin{array}{l}\text { a. The videos are presented according to the } \\
\text { characteristics of students }\end{array}$ & 4 \\
\hline & suitability & b. Suitability of videos with learning objectives & \\
\hline & & c. Ideal duration with goals & \\
\hline & & d. Interactive meal & \\
\hline \multirow[t]{2}{*}{4} & Creative in & a. The attraction of creativity in delivering messages & 2 \\
\hline & $\begin{array}{l}\text { pouring ideas } \\
\text { and creativity }\end{array}$ & $\begin{array}{l}\text { b. Flexibility in terms of providing time, place, teachers, } \\
\text { and teaching materials }\end{array}$ & \\
\hline \multicolumn{2}{|c|}{ Total } & & 17 \\
\hline
\end{tabular}

Table 4. Blueprint of Instrument Validity Video Animated Individual and Small Group Trial

\begin{tabular}{|c|c|c|c|}
\hline No & Aspect & Indicator & Item Number \\
\hline 1 & $\begin{array}{l}\text { Attract } \\
\text { students }\end{array}$ & $\begin{array}{l}\text { a. The attractiveness of the CD packaging (cover). } \\
\text { b. The attractiveness of the learning video display. } \\
\text { c. The attractiveness of the displayed image. } \\
\text { d. Clarity and attractiveness of colors presented. }\end{array}$ & 4 \\
\hline 2 & $\begin{array}{l}\text { Material } \\
\text { presentation }\end{array}$ & $\begin{array}{l}\text { a. The material presented is clear and appropriate. } \\
\text { b. The material presented is easy to understand. } \\
\text { c. The examples given in the material are easy to } \\
\text { understand and real. }\end{array}$ & 3 \\
\hline 3 & $\begin{array}{l}\text { Increase } \\
\text { student } \\
\text { attention }\end{array}$ & a. Learning videos can increase attention. & 1 \\
\hline 4 & Motivation & a. Learning videos can motivate learning. & 1 \\
\hline 5 & Voice clarity & $\begin{array}{l}\text { a. Narrator's voice clarity. } \\
\text { b. Music suitability. }\end{array}$ & 2 \\
\hline \multicolumn{2}{|c|}{ Total } & & 11 \\
\hline
\end{tabular}

The data in this study were converted using a five-scale conversion guideline to determine the validity of the developed media. Here's a scale five achievement rate conversion.

Table 5. Achievement Rate Conversion

\begin{tabular}{cc}
\hline Score Range & Classification/Predicate \\
\hline $4,01<X \leq 5,01$ & Very good \\
$3,33<X \leq 4,01$ & Good \\
$2,66<X \leq 3,33$ & Pretty good \\
$1,99<X \leq 2,66$ & Not good \\
$0,99<X \leq 1,99$ & Very Not Good \\
\hline
\end{tabular}

(Source: Koyan, 2012)

\section{RESULT AND DISCUSSION}

\section{Result}

Research on the development of project-based learning-oriented animation video media aims to determine the process and product validity. The development of this animated video goes through several stages, namely, analysis, design, and development. Analysis Phase, In the analysis phase, several steps are carried out, namely, analyzing the curriculum, student characteristics, and analyzing infrastructure. The implementation of curriculum analysis is carried out by analyzing KI, KD, indicators in teacher and student books used as a reference for media development. The analysis resulted in an agreement to use the theme book to save living things, especially on plant reproduction, to be used as a reference for 
developing animated video media. This topic certainly requires animated video media that can clarify, and the video displays moving animated images that resemble the actual situation. From the results of the analysis of student characteristics, it was found that some students had difficulties in accepting online learning and lost their motivation to learn, and active learning was seen from some students who experienced delays in collecting assignments. In the environmental analysis of facilities and infrastructure, it was found that it was carried out by observing the school environment and the facilities owned by SD Negeri 1 Banjarasem. This activity found that the facilities and infrastructure at SD Negeri 1 Banjarasem support project-based learning-oriented animation video media development. Most of the students have cellphone facilities to later be able to access the animated video media that was developed. If there are students who experience limited quota costs, students can take advantage of facilities and infrastructure in the form of laptops/computers and internet networks that are already owned by the school. From the analysis stage, it can be concluded that SD Negeri 1 Banjarasem is suitable for developing animated video media. Design Phase, at this stage, the developer collects materials in the form of designing an interesting learning animation video media script for elementary school students as well as collecting material for learning videos, identifying assignments/tests, compiling a product framework in the form of flowcharts, and compiling a budget for the costs needed in making learning animation video media.

\section{Development Stage}

At this stage, the product design is developed based on the results of the analysis and design stages. The development of this learning video media is as follows: creating content and selecting/making supporting media using Adobe Photoshop CS6, Adobe Illustrator 2019, Moho Pro 13, Adobe Audition CC 2019, and Adobe Premiere Pro CC 2019 software and developing student instructions/guidelines and teacher. Conduct formative evaluation and revision (expert test, individual test, and small group test). The data resulting from the expert assessment is then analyzed to determine its feasibility and revised if there are suggestions and inputs. Generate test reports/formative results. The development stage is presented in Figure 1, 2, 3, and 4.

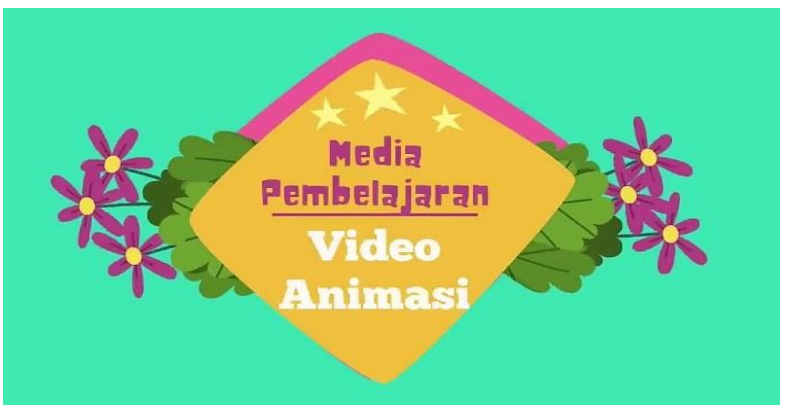

Figure 1. Animated Video Media Opening Section

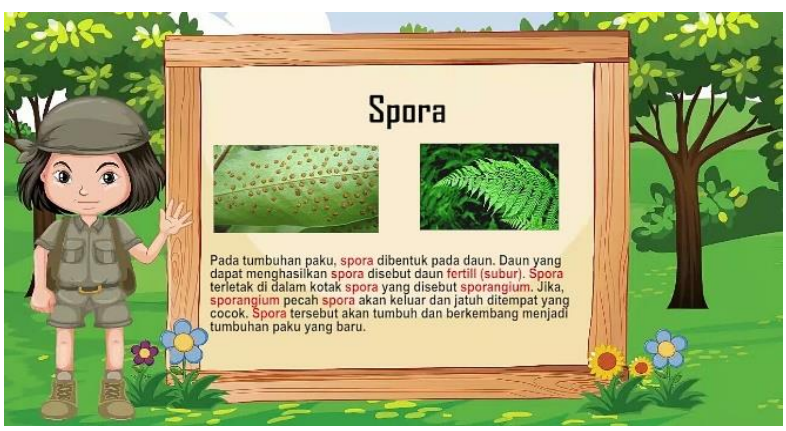

Figure 3. Contents of Learning Materials

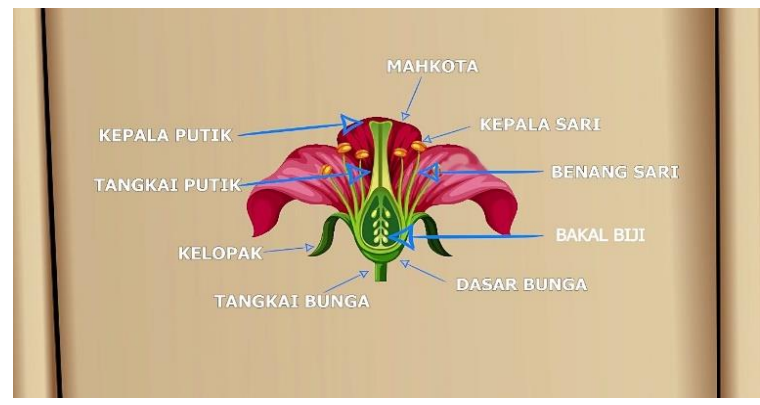

Figure 2. Learning Media Content Section Media

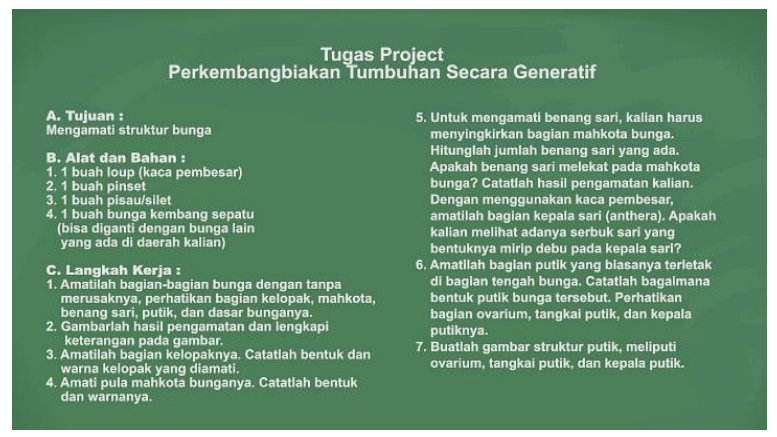

Figure 4. Animated Video Media Cover Section

The test of the validity of the project-based learning-oriented animated video media was carried out on content experts, design experts, media experts, individual trials, and small group trials of SD Negeri 1 Banjarasem students. The results of the validity test of animated video media, material content experts obtained 4.79 results with very good qualifications, learning design experts obtained 4.65 results with very good qualifications, learning media experts obtained 4.62 results with very good qualifications, individual trials obtained results 4.8 with very good qualifications, and the small group trial obtained 4.74 
results with very good qualifications. From these results, it can be concluded that project-based learningoriented animation video media is feasible to be developed.

When testing the validity of the animated video media, the experts gave some suggestions, input, and comments on the developed video. Some of the suggestions are, in the video, remove the special word on the goal, replace it with learning objectives, the title should not be combined with the class, type the class under the title, the illustration at 3:28 minutes adjusts to the student's mindset, on the flower picture show it with arrows give the text which parts of the flower are meant, in the sound effect there is some background music that is more dominant than the narrator, the experts give suggestions for more videos to be developed, but the quality of the animation video media developed is very good, as well as the material delivered is interesting, overall the animated video media developed is very interesting, clear, and easy to understand.

\section{Discussion}

This development research resulted in an animation video-oriented to Project-Based Learning on the theme Save Living Creatures for class VI SD. Animated video media is highly recommended and needed to support online learning because this media can be used flexibly in terms of time, place, and conditions without a network. This video is packaged on a CD and can be saved as a file. The animated video media that has been developed is included in the very good quality category, so this product is suitable to be used as a support for learning media. Learning media is a tool that can help the teaching and learning process and serves to clarify the meaning of the message conveyed so that it can achieve learning objectives better and more perfectly (Bambang, 2013). Animated videos are one example of learning media that can help the teaching and learning process and can clarify learning materials that display interesting animations. The project-based learning-oriented animation video product that has been developed has gone through several processes of expert testing and product testing and has been revised based on input and suggestions that have been received from experts who are competent in their fields.

In the first stage, the analysis stage is carried out by analyzing the curriculum, student characteristics and analyzing infrastructure (Robert Maribe Branch, 2009). At this stage, the data was obtained by conducting a needs analysis through direct interviews and field observations at SD Negeri 1 Banjarasem. The problem found is that there are differences in the character of students in the ability to receive learning. Some students will find it difficult if, in the learning process, no media assistance can clarify the material presented (F. Ibda, 2015). In addition, the lack of learning resources and the limited time of teachers to create innovative media causes learning resources to seem monotonous and boring for students. Facilities and infrastructure in schools are adequate to support the development of animated video media, namely internet access and laptops/computers. Then the information obtained is analyzed to be used as a reference in designing the media.

The next stage, namely the design stage, is carried out by making media designs according to the problems found in schools. At this stage, the developer designs an animated video media script that is considered capable of providing solutions to existing problems. In addition, developers identify tasks/tests, develop a product framework in the form of flowcharts, and prepare a budget for the costs needed in making animated video media. Materials that are by the curriculum are collected to be used as the contents of animated videos. In the third stage, development activities are carried out, namely the stage of realizing product designs or product development that has gone through the analysis and design stages. At this stage, the content and supporting media are created using Adobe Photoshop CS6, Adobe Illustrator 2019, Moho Pro 13, Adobe Audition CC 2019, and Adobe Premiere Pro CC 2019 software. The animated video media is designed in such a way that it is attractive to elementary students. In addition, the developer also makes the teacher and student instructions/guidelines, conducts formative evaluations and revisions (expert tests, individual tests, and small group tests). The data resulting from the expert's assessment were analyzed and concluded that the animated video media developed was feasible to use.

The animated video media that is developed certainly has advantages and disadvantages. Some of the advantages of the animated video media that have been developed are aspects of the content of the material contained in the video by the existing curriculum. The structure of the material already has the compatibility of basic competencies with indicators so that the material presented can add insight to students' knowledge. In addition, the initial material is related to students' prior knowledge, the evaluation used is appropriate, and the material presented is equipped with illustrations (examples) that can clarify the material presented. The learning design used also contributes to the media products developed so that this video is feasible to use. This can be seen from the material that is by the learning objectives with the ABCD format. The videos in the media are developed by the learning styles of elementary school children so that they attract interest and attention that can provide motivation and increase student understanding. The project-based learning-oriented animation video media that was 
developed has attractiveness in terms of visual quality seen from the animation displayed. Elementary school students are happy and interested in animated videos that contain moving pictures, like witnessing something that fits their world. The narrator's voice used in the video is simple, clear, and communicative. The opening video is also interesting, so students become interested in listening to the video material to the end. The aspect of the suitability of the video presentation already has the compatibility of the video with the learning objectives and the duration is by the target. This video can be used in a flexible time, place, teacher, and teaching materials so that this media is very easy and feasible to be used as a learning support media. Aspects that support this animated video media deserve to be developed that are seen from individual trials and small group trials. The video is considered interesting because it can increase students' interest through the video display that is presented so that students' attention is more focused and motivated. This description is in line with research conducted by (Dini Aria Farindhni, 2018; Margareta Widiyasanti \& Yulia Ayriza, 2018) which states that animated video media is effective in increasing students' learning motivation and democratic character. The material presented in the video is clear, by the curriculum, and easy to understand. So, it can be seen from this that project-based learningoriented animation video media is feasible to use. This is also in line with previous studies, which state that animated video media on the human immune system material is feasible to use (Linika, 2017). In addition to the advantages possessed by project-based learning-oriented animated video media, this media certainly still has several drawbacks, namely, if this media is used for online learning, it will require quite a lot of internet quota to download the video. This is because the quality of the HD video presented is very high. Disadvantages that are also owned in the process of making animated video media also require a lot of time and money. However, the shortcomings of this video media, when compared with the benefits provided to the education sector, these media deserve to be developed to support the learning process in the future.

\section{CONCLUSION}

Based on the results of research on the development of project-based learning-oriented animated video media on the theme of saving living things, especially on the topic of plant breeding for class VI SD, the qualifications are very good, so that project-based learning-oriented animation video media is feasible to use. Field trials cannot be carried out due to the Covid-19 pandemic. It is recommended for further researchers to be able to conduct further research on animated video products that can be tested in the field to determine the effectiveness of student activity in science learning.

\section{REFERENCES}

Agustien, R., Umamah, N., \& Sumarno, S. (2018). Pengembangan Media Pembelajaran Video Animasi Dua Dimensi Situs Pekauman di Bondowoso Dengan Model Addie Mata Pelajaran Sejarah Kelas X IPS. Jurnal Edukasi, 5(1), 19. https://doi.org/10.19184/jukasi.v5i1.8010.

Alessi, S.M dan Trollip, S. . (2001). Multimedia for learning: methods and development, 3nd ed. Pearson Education.

Apriansyah, M. R. (2020). Pengembangan Media Pembelajaran Video Berbasis Animasi Mata Kuliah Ilmu Bahan Bangunan di Program Studi Pendidikan Teknik Bangunan Fakultas Teknik Universitas Negeri Jakarta. Jurnal Pendidikan Teknik Sipil, 9(1), 1-11.

Ardianti, S. D., Pratiwi, I. A., \& Kanzunnudin, M. (2017). Implementasi Project Based Learning (Pjbl) Berpendekatan Science Edutainment Terhadap Kreativitas Peserta Didik. Refleksi Edukatika: Jurnal Ilmiah Kependidikan, 7(2). https://doi.org/10.24176/re.v7i2.1225.

Arsyad, A. (2013). Media Pembelajaran. Pt. Raja Grafindo Persada.

Baber, H. (2021). Modelling the acceptance of e-learning during the pandemic of COVID-19-A study of South Korea. The International Journal of Management Education, 19(2), 100503. https://doi.org/10.1016/j.ijme.2021.100503.

Bambang, C. K. dan S. (2013). Media Pembelajaran. Ghalia Indonesia.

Dewi, W. A. F. (2020). Dampak COVID-19 terhadap Implementasi Pembelajaran Daring di Sekolah Dasar. Edukatif: Jurnal Ilmu Pendidikan, 2(1), 55-61. https://doi.org/10.31004/edukatif.v2i1.89.

Dini Aria Farindhni. (2018). Pengembangan Media Video Animasi untuk Peningkatan Motivasi Belajar dan Karakter Demokratis Siswa Kelas V Sekolah Dasar. Pendidikan Karakter, 172-186.

Engelhardt, B., Johnson, M., \& Meder, M. E. (2021). Learning in the time of Covid-19: Some preliminary findings. International Review of Economics Education, 37, 100215. https://doi.org/10.1016/j.iree.2021.100215.

Fajar, G. S. (2019). Mokelis For Kids Modul Edukasi Listrik Sebagai Media Pembelajaran Keselamatan 
Listrik Anak Usia Dini. Jurnal Edukasi Elektro, 3(1). https://doi.org/10.21831/jee.v3i1.26017.

Guan, W., Ni, Z., Hu, Y., Liang, W., Ou, C., He, J., Liu, L., Shan, H., Lei, C., Hui, D. S. C., Du, B., Li, L., Zeng, G., Yuen, K.-Y., Chen, R., Tang, C., Wang, T., Chen, P., Xiang, J., ... Zhong, N. (2020). Clinical Characteristics of Coronavirus Disease 2019 in China. New England Journal of Medicine, 382(18), 1708-1720. https://doi.org/10.1056/NEJMoa2002032.

Herliandry, L. D., Nurhasanah, N., Suban, M. E., \& Kuswanto, H. (2020). Pembelajaran Pada Masa Pandemi Covid-19. JTP - Jurnal Teknologi Pendidikan, 22(1), 65-70. https://doi.org/10.21009/jtp.v22i1.15286.

Hincal, E., \& Alsaadi, S. H. (2021). Stability analysis of fractional order model on corona transmission dynamics. Chaos, Solitons \& Fractals, 143, 110628. https: //doi.org/10.1016/j.chaos.2020.110628.

Ibda, F. (2015). Perkembangan Kognitif: Teori Jean Piaget. Intelektualita, 3(1), 242904.

Ibda, Fatimah. (2015). Perkembangan Kognitif : Teori Jean Piaget. Intelektualita, 3(1), 27-38.

Isya', M. A. (2017). Pengembangan model pembelajaran instruksional design dengan model Addie mata pelajaran PAI pada materi mengulang-ulang hafalan Surah Al Ma'un dan al Fil secara klasikal, kelompok dan individu kelas V SDN Gedongan 2 Kota Mojokerto. Ta'dibia: Jurnal Ilmiah Pendidikan Agama Islam, 7(1), 71. https://doi.org/10.32616/tdb.v7.1.37.71-80.

Jatira, Y., \& S, N. (2021). Fenomena Stress dan Pembiasaan Belajar Daring dimasa Pandemi Covid-19. Edukatif : Jurnal Ilmu Pendidikan, 3(1), 35-43. https://doi.org/10.31004/edukatif.v3i1.187.

Jogezai, N. A., Baloch, F. A., Jaffar, M., Shah, T., Khilji, G. K., \& Bashir, S. (2021). Teachers' attitudes towards social media (SM) use in online learning amid the COVID-19 pandemic: the effects of SM use by teachers and religious scholars during physical distancing. Heliyon, 7(4), e06781. https://doi.org/10.1016/j.heliyon.2021.e06781.

Juriah, J., \& Juanengsih, N. (2016). Pembelajaran Konstruktivisme Berbantu Media Video/Animasi Untuk Meningkatkan Hasil Belajar Biologi Siswa Kelas X MIPA 3. EDUSAINS, 8(1). https://doi.org/10.15408/es.v8i1.3801.

Kusumadewi, R. F., Yustiana, S., \& Nasihah, K. (2020). Menumbuhkan Kemandirian Siswa Selama Pembelajaran Daring Sebagai Dampak Covid-19 Di SD. Jurnal Riset Pendidikan Dasar (JRPD), 1(1). https://doi.org/10.30595/.v1i1.7927.

Margareta Widiyasanti \& Yulia Ayriza. (2018). Pengembangan Media Video Animasi Untuk Meningkatkan Motivasi Belajar Dan Karakter Tanggung Jawab Siswa Kelas V. Pendidikan Karakter.

Musfiqon. (2012). Pengembangan Media dan Sumber Pembelajaran. PT. Prestasi Pustakaraya.

Mustafida, F. (2016). Kajian Media Pembelajaran Berdasarkan Kecenderungan Gaya Belajar Peserta Didik Sd/Mi. MADRASAH, 6(1), 20. https://doi.org/10.18860/jt.v6i1.3291.

Noviyanto, T. S. H., Juanengsih, N., \& Rosyidatun, E. S. (2015). Penggunaan Media Video Animasi Sistem Pernapasan Manusia Untuk Meningkatkan Hasil Belajar Biologi. EDUSAINS, 7(1). https://doi.org/10.15408/es.v7i1.1215.

Permatasari, I. S., Hendracipta, N., \& Pamungkas, A. S. (2019). Pengembangan Media Pembelajaran Video Animasi Hands Movedengan Konteks Lingkungan Pada Mapel IPS. Jurnal Pendidikan Dan Pembelajaran Dasar, 6(1). https://doi.org/https://doi.org/10.24042/terampil.v6i1.4100.

Pradana, D., Abidin, Z., \& Adi, E. (2020). Pengembangan Video Animasi Pembelajaran Subtema Pembentukan Karakter untuk Siswa SDLB Tunarungu. JINOTEP (Jurnal Inovasi Dan Teknologi Pembelajaran): Kajian Dan Riset Dalam Teknologi Pembelajaran, 7(2), 96-106. https://doi.org/10.17977/um031v7i22020p096.

Putri, L. A., \& Dewi, P. S. (2020). Media Pembelajaran Menggunakan Video Atraktif pada Materi Garis Singgung Lingkaran. Mathema: Jurnal Pendidikan Matematika, 2(1), 32. https: //doi.org/10.33365/jm.v2i1.568.

Ripoll, V., Godino-Ojer, M., \& Calzada, J. (2021). Teaching chemical engineering to biotechnology students in the time of COVID-19: Assessment of the adaptation to digitalization. Education for Chemical Engineers, 34, 21-32. https://doi.org/10.1016/j.ece.2020.11.001.

Robert Maribe Branch. (2009). Intructional Design: The ADDIE Approach. Springer.

Shah, S. S., Shah, A. A., Memon, F., Kemal, A. A., \& Soomro, A. (2021). Aprendizaje en línea durante la pandemia de COVID-19: aplicación de la teoría de la autodeterminación en la "nueva normalidad." Revista de Psicodidáctica. https://doi.org/10.1016/j.psicod.2020.12.004.

Singhal, T. (2020). A Review of Coronavirus Disease-2019 (COVID-19). The Indian Journal of Pediatrics, 87(4), 281-286. https://doi.org/10.1007/s12098-020-03263-6.

Sultia Linika Sari. (2017). Pengembangan Media Pembelajaran Berbasis Video Animasi dalam Smartphone pada Materi Sistem Kekebalan Tubuh Manusia untuk Siswa Kelas XII di SMA Negeri 5 Banda Aceh. Prosiding Seminar Nasional Biotik.

Suprianta dan Mochamad. (2009). Konsep Dasar Desain Pembelajaran. Rineka Cipta. 
Sutirman. (2013). Media \& Model-model Pembelajaran Inovatif. Graha Ilmu.

Tambrallimath, V., Keshavamurthy, R., Badari, A., Ramesh, L., \& Raj, G. (2021). Emergence of additive manufacturing in global scale during the crisis of 2019-nCoV (novel corona virus). Materials Today: Proceedings. https://doi.org/10.1016/j.matpr.2020.12.999.

Tang, Y. M., Chen, P. C., Law, K. M. Y., Wu, C. H., Lau, Y., Guan, J., He, D., \& Ho, G. T. S. (2021). Comparative analysis of Student's live online learning readiness during the coronavirus (COVID-19) pandemic in the higher education sector. Computers \& Education, 168, 104211. https://doi.org/10.1016/j.compedu.2021.104211.

Trianingsih, R. (2016). Pengantar Praktik Mendidik Anak Usia Sekolah Dasar. Al Ibtida: Jurnal Pendidikan Guru MI, 3(2), 197. https://doi.org/10.24235/al.ibtida.snj.v3i2.880. 